XXXIII. Characters of various new Groups and Species amongst the Coprophagous Lamellicorn Beetles. By J. O. Westwood, F.L.S. \&c.

[Read 7th March, 1842, \&c.]

As considerable interest is attached to the various types of form amongst the species of insects known by the ordinary name of sacred beetles (on account of the veneration with which the Egyptians regarded those particular species which are inhabitants of their strange land,) I need offer no apology in submitting to the notice of the members of this Society descriptions and figures of various new and interesting species belonging to that family lately arrived in this country.

One of these insects possesses characters differing so much from those of all the rest of the true and typical subgenus Heliocantharus, to which it is most nearly allied, that I am induced to regard it as possessing a higher rank than that of a mere species of that group; at the same time it is to be admitted that it seems scarcely entitled to an equal rank with the types of form which Mr. MacLeay has named Mnematium, Pachysoma and Gymnopleurus.

\title{
Sebasteos, Westw.
}

Typus Scarabæorum sacrorum, Heliocantharo magis affinis.

Antennæ articulo 3 tio et 4to 5 to duplo longioribus, subæqualibus, 5 to et 6 to brevibus, pateriformibus; $7 \mathrm{mo}$, 8 vo et 9 no clavam angustiorem formantibus. Caput maximum. Clypeus radiatus, dentibus duobus anticis obtusis, intermediis latis truncatis, posticis duobus angulatis; clypeus subtus antice dentibus tribus deflexis armatus. Tibiæ anticæ angulatæ, extus 4-dentatæ, dentibus duobus apicalibus inter se remotis, intus serratulæ denteque medio armatæ. Tarsi antici obsoleti; postici 2 articulis subclavatis verticillatis.

Of these characters the variation in the relative size of the intermediate joints of the antennæ, the large size of the head, the curious horns with which the under side of the projecting lobes of the clypeus are armed, the curved fore legs armed on the inside beyond the middle with a short tooth, and the form of the hind tarsi, are those by which it is most easily distinguished from the true Heliocanthari. 
Sp. unica. Scarabaus (Sebasteos) Galenus, Westw. (Pl. XVII. fig. 1.)

Niger, nitidus, capite magno varioloso-punctato, pronoto punctato, margine postico lævi; elytris stria suturali alterisque quinque tenuibus sub lente punctatis ; disco tenuissime punctato; pronoto utrinque versus marginem lateralem puncto majori impresso notato.

Long. corp. lin. 14.

Habitat in Africa meridionali. D. Burke.

In Mus. Soc. Zool. Lond.

This is one of the fine species of insects brought to England by Mr. Burke, and presented by the Earl of Derby to the Zoological Society of London, and which were captured in the hilly country lying between $25^{\circ}$ and $26^{\circ}$ south lat. and $27^{\circ}$ and $28^{\circ}$ east long.

Plate XVII. fig. 1 , the insect of the natural size; $1 a$, the head seen side. ways; $1 b$, the mentum and labial palpus; $1 c$, the antenna; $1 d$, intermediate tibia and tarsus; $1 e$, posterior tarsus.

Sceliages, Westw. (in Trans. Zool. Soc. ii. p. 159.)

Sceliages Hippias, Westw. (Pl. X VII. fig. 2.)

Niger, nitidus, capite sub lente tenuissime punctato; clypeo cornubus duobus intermediis porrectis; pronoto fere lævi, elytrisque sublævibus et minus nitidis, singulo striis 6 vix discernendis; tibiis anticis haud in medio angulatis, extus 4-dentatis et serrulatis, metasterno antice producto et convexoprominulo.

Long. corp. lin. 8 .

Habitat in Africa meridionali. D. Burke.

In Mus. Soc. Zool. Lond.

This species is distinguished from the Sceliages Iopas, described by me in the Transactions of the Zoological Society, by its less dilated form, as well as by the characters mentioned above.

Plate XVII. fig. 2 , the insect of the natural size; $2 a$, the antenna; $2 b$, the clava of the antenna seen from the opposite side; $2 c$, anterior tibia; $2 d$, base of middle tarsus; $2 e$, posterior tarsus.

\section{Epilissus, Dej. Cat.}

The genus Epilissus of Dejean's Catalogue, adopted by Reiche in his synopsis of the Ateuchideous genera, published in the 
Trans. Ent. Soc. Vol.1V.PL. 16.

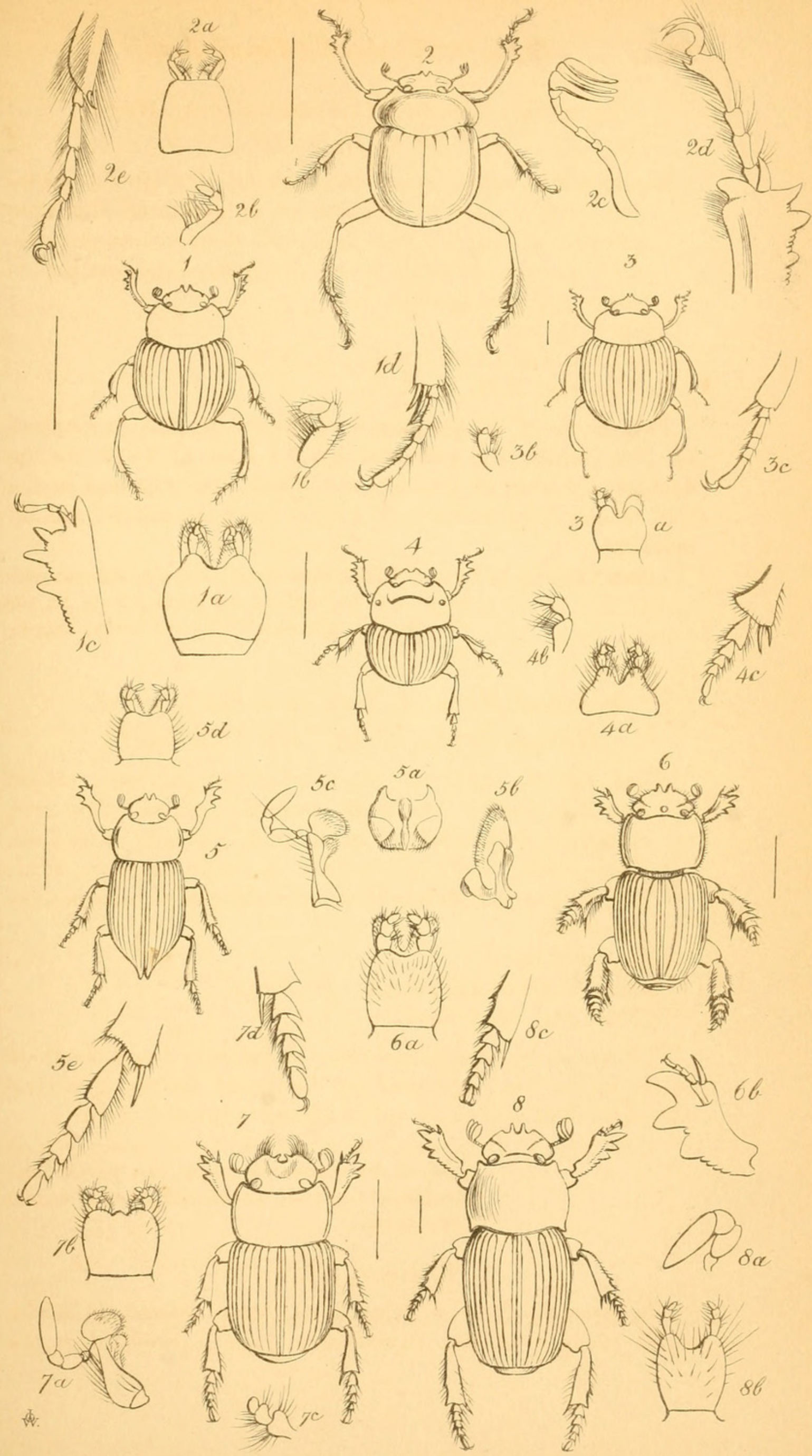





\section{.}


Trans.Ent.Soc. Vol. IV. Pl.XVII.

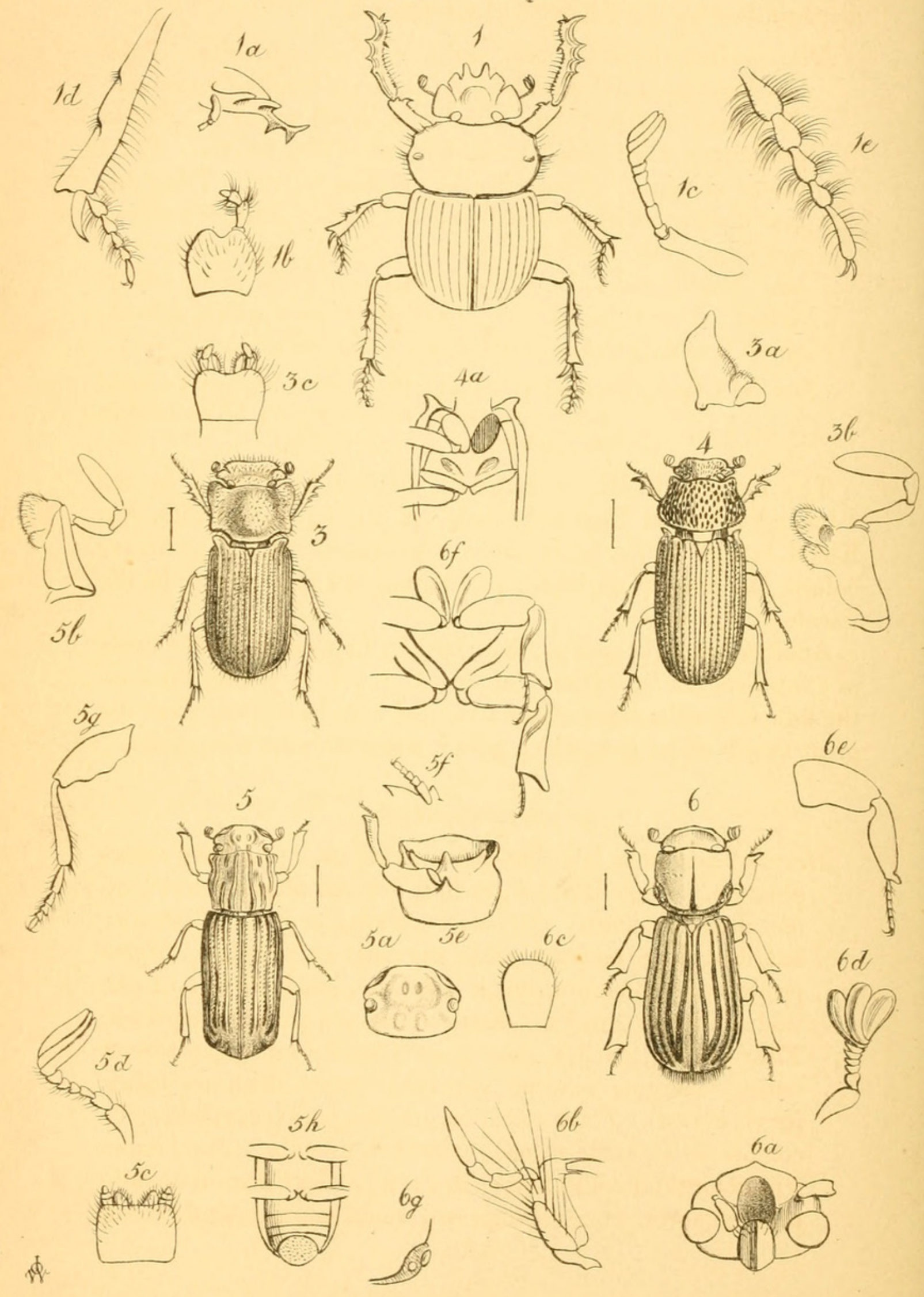


"Revue Zoologique," (1841, p. 212,) consists of Madagascar insects which differ very much from each other in several respects, so that I am induced to describe several of them as the types of respective subgenera. Retaining the Canthon prasinus of Klug, (Mad. Col. p. 73,) as the type of the typical subgenus, we find it distinguished by the following characters :-

Mentum latum, suborbiculare, antice valde emarginatum. Palpi labiales crassi, articulo ultimo præcedenti longitudine æquali, Prothorax lateribus fere rotundatis, haud reflexis. Elytra prothorace manifeste latiora, fere rotundata striata. Pedes parum elongati. Femora brevia, subtriangularia. Tibice anticæ elongato-triangulares, depressæ, rectæ; margine externo serrulato, extus acute tridentatæ. Tibice 4 posticæ curvatæ, basi gracillimæ, apice sensim dilatato. Tarsi antici minutissimi ; 4. postici tibiarum fere dimidio longitudine, articulo basali breviori, ultimo simplici, unguibus curvatis.

Plate XVI. fig. 1, Epilissus prasinus; $1 a$, instrumenta labialia ; $1 b$, labial palpus ; $1 c$, anterior tibia and tarsus; $1 d$, intermediate tibia and tarsus.

The Canthon viridis of Latreille, figured by Guerin in the "Iconographie du Règne Animal," pl. 21, fig. 3, (Griffith, An. Kingd. Ins. pl. 45, fig. 4,) is evidently congeneric with E. prasinus; indeed Dr. Klug (Col. Mad. p. 73) suggests that it may be the female of that species.

Another beautiful species, described by Laporte under the name of Circellium nitidum (Hist. Nat. Ins. Col. vol. 2, p. 66), presents the following subgeneric characters, and may be named, from the great length of its feet, which give it a resemblance to a spider,

\section{Arachnodes, Westw.}

Mentum basi latius, lateribus convergentibus, apice haud emarginatum. Palpi labiales graciles, articulo ultimo præcedenti fere dimidio minori. Antennarum clava elongata. Prothorax lateribus pone medium valde angulatis et reflexis. Elytra prothorace vix latiora, magis quadrata, haud striata. Pedes valde elongati, graciles. Femora elongata, parum compressa. Tibice anticæ graciles, ante apicem subito intus curvatæ et setosæ, margine externo serrulato, apice dentibus tribus parvis obtusis. Tibiæe 4 posticæ graciles, parum curvatæ, apice compresso et valde setoso, calcaribus minutis. Tarsi antici fere tibiarum dimidio longitudine; 4 postici tibiarum dimidio plus longiores, omnes compressi, valde setosi, articulo basali 
minimo, 2ndo duobus sequentibus longiori, 5 to latiori ad apicem subtus in spinam parvam producto; unguibus valde curvatis.

Plate XVI. fig. 2, Arachnodes nitidus; $2 a$, instrumenta labialia ; $2 b$, labial palpus; $2 c$, antenna; $2 d$, anterior tarsus; $2 e$, posterior tarsus.

The Circellium clypealum of Laporte, (Hist. Nat. Ins. Col. vol. 2, p. 67,) will form another subgenus, distinguished by its very depressed form, short prothorax, having the sides rounded, the elytra striated, the mesosternum channelled down the middle, and the tibiæ very much curved.

The insects above described are of comparatively large size, being more than half an inch long and of splendid green tints; but there are several much more minute species of a black colour, also natives of Madagascar, which are, in fact, the pygmies of the family of the sacred beetles, not exceeding one-eighth of an inch in length. They may be characterized thus:-

\section{Nanos, Westw.}

Antennarum clava brevis, subrotundata. Mentum in medio latius, antice valde emarginatum. Palpi labiales brevissimi, lati; articulis 1 et 2 fere æqualibus, 3 tio minimo. Prothorax lateribus fere rotundatis, haud reflexis. Elytra prothorace evidenter latiora, fere rotundata, lævissime striata. Pedes parum elongati, sublæves. Femora postica subovalia. Tibice anticæ curvalæ, depressæ, sensim latiores, apice extus 3-dentatæ; tibiæ 4 posticæ curvatæ, versus apicem paullo latiores. Tarsi antici mediocres, 4 postici longiores, unguibus valde curvatis.

Circellium pygmaus, Laporte. Hist. Nat. Col. 2, p. 67, is the type of this subgenus.

Plate XVI. fig. 3 , Nanos pygmeus; $3 a$, instrumenta labialia; $3 b$, labial palpus; $3 c$, posterior tibia and tarsus.

The remaining groups, which I propose to describe in this communication, belong to that section of the Scarabcide which possess short and triangularly dilated posterior tibix, and the tarsal joints of the hind feet gradually narrowed, of which Copris is the typical genus.

Macroderes, Westw.

Corpus fere hæmisphæricum. Clypeus antice emarginatus, laciniis obtusis, postice transverse carinatus. Mentum sub- 


\section{$2 \mathrm{BHL}$ Biodiversity Heritage Library}

Westwood, J. O. 1847. "XXXIII. Characters of various new Groups and Species amongst the Coprophagous Lamellicorn Beetles." Transactions of the Entomological Society of London 4, 225-232.

https://doi.org/10.1111/j.1365-2311.1847.tb01357.x.

View This Item Online: $\underline{\text { https://www.biodiversitylibrary.org/item/51008 }}$

DOI: https://doi.org/10.1111/j.1365-2311.1847.tb01357.x

Permalink: https://www.biodiversitylibrary.org/partpdf/21741

\section{Holding Institution}

Smithsonian Libraries

\section{Sponsored by}

Smithsonian

\section{Copyright \& Reuse}

Copyright Status: Public domain. The BHL considers that this work is no longer under copyright protection.

This document was created from content at the Biodiversity Heritage Library, the world's largest open access digital library for biodiversity literature and archives. Visit BHL at https://www.biodiversitylibrary.org. 